\title{
OBSERVACIONES DE CAMPO EN LA FORMA DE CAPTURAR EL ALIMENTO POR ALGUNAS AVES
}

\author{
De la Peña, M. R. ${ }^{1}$
}

\begin{abstract}
RESUMEN
Se detallan las observaciones realizadas en el campo con relación a la forma que tienen, para tomar el alimento 101 especies de aves Passeriformes.

Se especifica el sustrato de donde es tomado, a que altura realizan la maniobra de captura y el tipo de alimento obtenido.

Palabras clave: aves, alimentación, maniobras de captura, Argentina.
\end{abstract}

\section{SUMMARY}

Fieldwork about the wag in which some bird species take food.

The observations carried out the field related to the way in which 101 Passeriformes bird species take food are detailed in this paper.

The substratum where food is taken, the height in which they carry out the capture strategies and the sort of food what is obtained are also specified.

Key words: birds, feeding, capture strategies, Argentina. 